\title{
SELECTION MODEL OF REPRESENTATIVE ITEMS FOR THE SUBCONTRACTORS' COST INDEX IN MULTI-FAMILY HOUSING PROJECTS
}

\author{
Sung-Chul Park ${ }^{1}$, TaeHoon Hong ${ }^{2}$, Kyo-Jin Koo ${ }^{3}$, Chang-Taek Hyun ${ }^{4}$ \\ ${ }^{1}$ Educational Facilities Research and Management Center, \\ Korean Educational Development Institute, Seoul, Korea \\ ${ }^{2}$ Dept of Architectural Engineering, Yonsei University, Seoul, Korea \\ ${ }^{3,4}$ Dept of Architectural Engineering, University of Seoul, Seoul, Korea \\ E-mails: ${ }^{1}$ pcs9530@kedi.re.kr; ${ }^{2}$ hong7@yonsei.ac.kr (Corresponding Author); \\ ${ }^{3}$ kook@uos.ac.kr; ${ }^{4}$ cthyun@uos.ac.kr \\ Received 10 Mar. 2009, accepted 10 Feb. 2010
}

\begin{abstract}
Price index has played an important role in measuring the past performance of an industry, which it does by tracking the cost of the items used in the industry. It is the most widely used industry performance indicator because a small number of representative items covers a wide range of costs. The construction industry consists of various facility types that can be organized into many subcontractors' works. Unfortunately, the existing cost indexes have difficulty monitoring the fluctuation of the subcontractors' costs since they select representative items in macro-scale terms, such as the type of construction or facility. Therefore, this study was conducted to develop a selection model that can select the effective representative items included in the subcontractors' costs. To determine the characteristics of the subcontractors' costs, the curve estimation function of SPSS ${ }^{\circledR} 12.0$ for Windows was applied to the priced bills of quantities of 30 multifamily housing projects. The results of the analysis show that the relationship between the coverage ratio and the percentage of the number of representative items follows Pareto's principle. Based on this, a selection model of representative items was developed, using the tangent function. The case study that was conducted to verify the usability of the model revealed that the proposed model can efficiently select the effective representative items from the cost items of each subcontractor's work included in multi-family housing projects.
\end{abstract}

Keywords: housing projects, representative items, selection model, price indexes, subcontractors' costs, tangent function, cost index.

\section{Introduction}

Price index, which can be divided into an index formula and an index number, has long been widely used as an effective indicator of the past performance of an industry. The construction cost index and building cost index, which were published by Engineering News Report and RSMeans, and the highway construction cost index (HCCI) issued by the Department of Transportation (DOT), are often used in adjusting construction costs and in completing budget costs (Fleming and Tysoe 1991). Although many indices have been developed to monitor the price fluctuations in the economy, these indices use the following procedure to secure maximum efficiency with minimum data collection cost: (1) selecting representative items; (2) calculating the weights of the representative items; and (3) regularly applying the price fluctuations.

A construction project type (e.g., multi-family housing project) is composed of a set of many works (e.g., reinforced concrete (RC), masonry, water proofing). The existing indices were developed for measuring the price fluctuation of the construction cost. Therefore, it is difficult to use these indices because the items included in the works, which account for a small portion of the construc- tion cost, such as painting and plastering, are selected as representative items. In other words, most subcontractors need to develop a subcontractor's cost index that can monitor the price fluctuation in a specific subcontractor's cost.

An index number is generally calculated as follows: 1) selecting representative items, 2) developing or selecting an index formula, and 3) calculating index numbers. Unlike previous studies which have been developed for selecting an index in economics, previous studies in the construction industry have focused on the following two areas.

One is to improve the practicality of calculating index numbers (ENR 2005; Hassanein and Khalil 2006). Most of the previous studies have used a small number of representative items which account for low coverage ratio (total sum of representative items / total sum of the collected items) selected by subjective judgments.

Another is to forecast the future index numbers through statistical approaches such as regression model, time series analysis, and so forth (Bates and Dawood 1997; Dawood 1999; Wang and Mei 1996). However, these studies did not address the way how to select the representative items but emphasized the importance of forecasting methodologies. 
Over the whole world, developing an effective selection model is one of global research subjects. For example, previous researches on selecting an optimized construction machine presented a number of selection models using a lot of selection methods, such as liner programming, expert system, ELECTRE III, and so forth (Ulubeyli and Kazaz 2009). Nevertheless, it is clear that research on the selection of representative items is still in the early stage despite its significance.

In practice, representative items are selected by fixed value in Korea (e.g., more than $80 \%$ of the total cost) (The Bank of Korea 2005). Such method can either remove the effective data or select the ineffective data. Therefore, this study was conducted to develop a selection model that can be used by subcontractors in selecting effective representative items. Although the construction industry consists of many facility types, the multi-family housing project type was selected as a representative project type in this study because the ratio of the number of general contractors focusing on residential apartment projects to the total number of general contractors in Korea is $48.92 \%(6,239 / 12,754)$, which indicates that most of the subcontractors and general contractors in Korea are interested in the project type. Besides, the construction projects in Korea have high homogeneity. For example, steel bar (HD 13) is used in almost all the multi-family housing projects in Korea, and similar weights, which pertain to the ratio of their costs to the total costs, are also used for almost all such projects. This homogeneity can maximize the usability of a model.

To develop a selection model of representative items (SMRI), first, the roles of representative items, and their weights, were analyzed by examining the Laspeyres index formula, and the importance of the coverage ratio (CR), which pertains to the representativeness of an index number, was revealed. Second, the characteristics of the subcontractor's costs were determined, which is very critical in establishing a development direction. For this purpose, the priced bills of quantities (BOQs) of 30 multi-family housing projects were collected. Third, an SMRI was developed by employing a mathematical approach. Finally, the proposed SMRI was applied to 10 multifamily housing projects as a case study, to validate the usability of the model.

\section{Coverage ratio and number of representative items}

The most widely known index formula in the construction industry and in the different economic areas is the Laspeyres index formula $\left(P_{L}\right)$ shown in equations (1) and (2) (Balk 1995; Tim 2005; U.S. Army Corps of Engineers 2000; KICT 2004; Kim and Kim 2005).

$$
\begin{gathered}
P_{L}=\sum_{i=1}^{n} S_{i}^{0} \frac{p_{i}^{1}}{p_{i}^{0}}, \\
S_{i}^{0}=\frac{p_{i}^{0} q_{i}^{0}}{\sum_{i=1}^{n} p_{i}^{0} q_{i}^{0}},
\end{gathered}
$$

where $p_{i}^{0}$ is the contract unit price of the $\mathrm{i}^{\text {th }}$ representative item in base period $0, p_{i}{ }^{1}$ is the contract unit price of the $\mathrm{i}^{\text {th }}$ representative item in comparison period $1, q_{i}^{0}$ is the quantity of the $i^{\text {th }}$ representative item in base period 0 , and $S_{i}^{0}$ is the weight of the $\mathrm{i}^{\text {th }}$ representative item in base period 0 .

In this paper, the characteristics of the Laspeyres index formula were determined by applying Table 1 to equations (1) and (2). For example, the weight of the concrete was determined by calculating the ratio of its cost to its sum $(0.048=5,000 / 100,000)$. The weight of the steel bar was computed by subtracting the weight of the concrete from 1 .

Table 1. Sample Calculation of an Index Number

\begin{tabular}{lccccc}
\hline \multicolumn{1}{c}{ Item } & $\begin{array}{c}(1) \\
p_{i}{ }^{0}\end{array}$ & $\begin{array}{c}(2) \\
p_{i}{ }^{1}\end{array}$ & $\begin{array}{c}(3) \\
q_{i}{ }^{0}\end{array}$ & $\begin{array}{c}(4)=(1) \times(3) \\
\text { Cost }\end{array}$ & $\begin{array}{l}(5) \\
S_{i}{ }^{0}\end{array}$ \\
\hline Concrete & 50 & 60 & 100 & 5,000 & 0.048 \\
\hline Steel Bar & 500 & 600 & 200 & 100,000 & 0.952 \\
\hline Sum & & & & 105,000 & 1 \\
\hline
\end{tabular}

As shown in equation (3), the price fluctuation in each item $\left(p_{i}{ }^{1} / p_{i}{ }^{0}\right)$ is applied to its weight. The index number can then be calculated by multiplying the base period's index number (100) by the sum of each item's index number.

$$
P_{L}=\left(\left(0.048 \times \frac{60}{50}\right)+\left(0.952 \times \frac{600}{500}\right)\right) \times 100=120 .
$$

When $S_{i}^{0}$ has been fixed, $p_{i}{ }^{1}$ will be needed only for updating the index number. This is why the Laspeyres index formula has been the most widely used in this area (IMF 2004; The World Bank 2006). Given this situation, the selection of representative items is very crucial for the accurate reflection of populations.

The California Department of Transportation (Caltrans 2006) and the Washington Department of Transportation (WSDOT 2006) calculate HCCI by selecting seven bid items whose weights are high in terms of highway construction cost. This index has been announced quarterly since 1990, its base year. In addition, the Louisiana Department of Transportation analyzes the historical data from 1984 to 1997 and calculates HCCI by selecting five representative items (aggregates, pavement concrete, structural concrete, steel bars, and asphalts), which occupy over $50 \%$ of the weights in the total costs (Wilmot and Cheng 2003). Although the representative items used in three DOTs may somewhat differ, they are identical in that they all apply only a small number of representative items, which covers a wide range of construction costs, to the Laspeyres index formula.

Generally, a facility consists of numerous representative projects, which include many representative items. The representativeness of the facility logically depends on the number of representative items (NRI). It is difficult, however, to conduct a survey on the prices and quantities of all the collected items due to the limited resource of a compiler. As some items have higher weights 


\begin{tabular}{|c|c|c|c|c|c|c|c|c|c|c|}
\hline \multirow{3}{*}{ 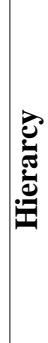 } & Level 1 & & & & $\begin{array}{r}\text { Represe } \\
(8\end{array}$ & $\begin{array}{l}\text { ntative } \\
\text { 30/100 }\end{array}$ & Facilit & & & \\
\hline & \multirow{2}{*}{\begin{tabular}{|l|l} 
& Level 2 \\
& Level 3
\end{tabular}} & \multicolumn{3}{|c|}{$\begin{array}{c}1^{\text {st }} \text { Representative Project } \\
\text { (500/500) }\end{array}$} & \multicolumn{3}{|c|}{$\begin{array}{l}\ldots \ldots \\
(150)\end{array}$} & \multicolumn{3}{|c|}{$\begin{array}{c}\mathrm{n}^{\text {th }} \text { Representative Project } \\
\text { (330/350) }\end{array}$} \\
\hline & & \begin{tabular}{|c|}
1 \\
Steel Bar \\
$(150)$ \\
\end{tabular} & $\begin{array}{c}2 \\
\ldots \ldots . . \\
(250) \\
\end{array}$ & $\begin{array}{c}\text { (3) } \\
\text { Form } \\
(100)\end{array}$ & $\begin{array}{l}\text { Steel Bar } \\
\quad(50)\end{array}$ & $\begin{array}{l}\ldots \ldots \\
(70)\end{array}$ & $\begin{array}{l}\text { Form } \\
(30)\end{array}$ & $\begin{array}{c}\text { (4) } \\
\text { Steel Bar } \\
(200) \\
\end{array}$ & $\begin{array}{l}\text { (5) } \\
\ldots \ldots \\
(20)\end{array}$ & $\begin{array}{c}\text { (6) } \\
\text { Form } \\
(130) \\
\end{array}$ \\
\hline
\end{tabular}

Fig. 1. Structure of a construction data resource

in the total costs, in practice, the representative items that have high weights are selected in calculating the index numbers. Selecting a number of representative items that is too small, however, may cause a low coverage ratio (CR) $(\mathrm{CR}=$ (total sum of representative items / total sum of the collected items) $\times 100$ ) on a representative facility. A low CR indicates that the price index has not fully reflected the characteristics of a representative facility.

Let us assume the data resources shown in Fig. 1. The squares with bold lines represent the representative facility, projects, and items selected among various facilities, projects, and items for the calculation of the index number. Moreover, the number inside each square shows (i) the total sum that can be explained by the selected representative projects or representative items, and (ii) the total sum that can be explained by all the collected items. For example, " 330 " of the $\mathrm{n}^{\text {th }}$ representative project in "level 2" of Fig. 1 represents the total sum of items that were selected as representative items (330 = steel bar $(200)+$ form (130)). " 350 " of the $\mathrm{n}^{\text {th }}$ representative project in "level 2" represents the total sum, including the amount (20) of items (illustrated by number (5) in Fig. 1) that were not selected as representative items. As shown in Fig. 1, a representative facility has 83\% representativeness by the selected representative items (illustrated by numbers (1), (2), (3), (4), and (6) in Fig. 1) and representative projects $(83 \%=((500+330) /(500+150+$ $350)) \times 100)$. Even though CR can increase as NRI increases, it is necessary to select effective representative items in terms of their efficiency.

\section{Characteristics of the subcontractor's costs}

It is possible to select representative items under the hypothesis that a small number of representative items can cover a wide range of costs. This is very similar to Pareto's principle (20\% of the items are responsible for $80 \%$ of the cost) (Barrie and Paulson 1992). For this reason, the characteristics of the subcontractors' costs were determined in this study, using the priced BOQs of 30 multi-family housing projects completed between 2003 and 2005 (about 25 works per project). The projects have various volumes because of the reliability of the result (gross floor area: 17,539 145,884 $\mathrm{m}^{2}$; number of floors: $4 \sim 15)$. The curve estimation function of SPSS ${ }^{\circledR} 12.0$ was used to determine the relationship between CR and NRI. The function provides 12 estimation models (e.g., inverse, quadratic, and cubic), including the linear model.
Prior to the curve estimation, the unit of NRI was changed into a percentage called "percentage of NRI (PNRI)" because the items of each project somewhat differ. If NRI is used for the curve estimation, it is difficult to know whether the subcontractors' costs follow Pareto's principle. Let us assume that there are 10 items in an RC work, as shown in Table 2. The items are placed in an ascending order of weight (column (3)). The CR of each item is calculated by adding each weight and previous item's weight (e.g., $84=(0.44+0.4) \times 100)$.

Table 2. Calculation of CR and PNRI

\begin{tabular}{c|l|c|c|c|c}
\hline $\begin{array}{c}(1) \\
\text { No. }\end{array}$ & \multicolumn{1}{c|}{$\begin{array}{c}(2) \\
\text { Item }\end{array}$} & $\begin{array}{c}(3) \\
\text { Weight }\end{array}$ & $\begin{array}{c}(4) \\
\text { CR }(\%)\end{array}$ & $\begin{array}{c}(5) \\
\text { NRI }\end{array}$ & $\begin{array}{c}(6) \\
\text { PNRI (\%) }\end{array}$ \\
\hline 1 & Spacer (slab) & 0.01 & 100 & 10 & 100 \\
\hline & & & $:$ & & $:$ \\
\hline 7 & Steel bar (HD25) & 0.01 & 95 & 4 & 40 \\
\hline 8 & Steel bender & 0.10 & 94 & 3 & 30 \\
\hline 9 & Concrete (25-240-12) & 0.40 & 84 & 2 & 20 \\
\hline 10 & Carpenter & 0.44 & 44 & 1 & 10 \\
\hline
\end{tabular}

Note: $*$ NRI = number of representative items; $* * \mathrm{CR}=$ coverage ratio; ${ }^{* * *}$ PNRI $=$ percentage of the number of representative items

Due to the efficiency of the representative item, an item with a high weight should be preferentially selected rather than an item with a low weight (e.g., carpenter > concrete (25-240-12) > .. > spacer (slab)). In column (5), NRI 3 indicates that the $10^{\text {th }}, 9^{\text {th }}$, and $8^{\text {th }}$ items were selected as representative items, and NRI 4 indicates that the $10^{\text {th }}, 9^{\text {th }}, 8^{\text {th }}$, and $7^{\text {th }}$ items were selected. PNRI 40 in column (6) is the ratio of the selected representative items to the number of all the collected items $(40=(4 / 10) \times 100)$.

Fig. 2 shows the result of the application of the curve estimation function to the subcontractors' costs. Among the 12 estimation models, four were suggested as available models.

As shown in Table 3, the cubic model has the highest $\mathrm{R}^{2}$. An $\mathrm{R}^{2}$ near 1 means that the regressors are good at predicting the values of the dependent variable in the sample, and an $\mathrm{R}^{2}$ near 0 means they are not. This makes these statistics useful summaries of the predictive ability of the regression (Stock and Watson 2007). In Table 3, b0 is a constant, and $b 1, b 2$, and $b 3$ are coefficients. It is clear that the regression model of subcontractors' costs using CR and PNRI follows a curved line and not a linear line. 


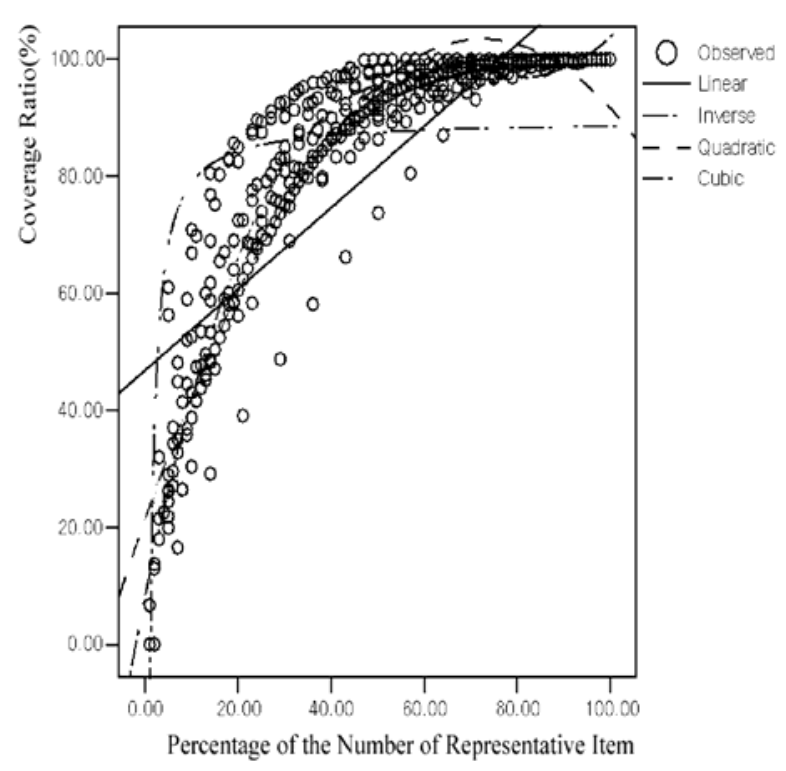

Fig. 2. Curve estimation of CR and PNRI

Table 3. Result of the Curve Estimation

\begin{tabular}{l|c|c|c|c|c|c}
\hline Model & $\mathrm{R}^{2}$ & Sig. & $b 0$ & $b 1$ & $b 2$ & $b 3$ \\
\hline Linear & 0.639 & 0.00 & 46.87 & 0.70 & & \\
\hline Inverse & 0.704 & 0.00 & 89.66 & -107.19 & & \\
\hline $\begin{array}{l}\text { Quad- } \\
\text { ratic }\end{array}$ & 0.866 & 0.00 & 21.33 & 2.2647 & -0.0156 & \\
\hline Cubic & 0.915 & 0.00 & 8.0813 & 3.949 & -0.058 & 0.003 \\
\hline
\end{tabular}

Note: *b0 = constant, **b1, b2, b3 = coefficients.

The regression equation of the cubic model is equation (4). According to this equation, $80 \% \mathrm{CR}$ is obtained in 28.17\% PNRI. This means that the hypothesis that a small number of representative items can cover a wide range of costs is reasonable. Based on this experimental proof, an attempt was made to develop an SMRI.

$\mathrm{Y}=8.0813+(3.9490 \mathrm{X})+\left(-0.0580 \mathrm{X}^{2}\right)+\left(0.0003 \mathrm{X}^{3}\right)$

where $\mathrm{X}$ is the PNRI (\%) and $\mathrm{Y}$ is the CR (\%).

\section{Selection model of representative items (SMRI)}

The CR, which shows how much an index number reflects the characteristics of a representative work, is an important element in the calculation of an index number. The Bank of Korea uses representative items over $1 / 10,000$ of the trading volume for selecting representative items with high CRs, to calculate the producer price index. To increase the CR, however, the PNRI should also be increased. This requires a longer time and greater costs for the collection and analysis of data regarding the representative items. Therefore, the selection of items with a high representativeness requires the acquisition of the maximum CR with the minimum PNRI.

As previously mentioned, the relationship between CR and PNRI in the subcontractors' costs follows a curved line. The initial part of the curved line has a steep slope because a small number of items accounts for a significant portion of the weights. The slope of the rest of the curve, however, becomes gentler geometrically as the weights of the items included in the rest of the curve are very light. If the point in which the curve's interior angle is at a minimum is selected, effective representative items that show a high representativeness with a small NRI can be selected. As shown in Fig. 2, effective representative items were selected in this paper by measuring the interior angle $\left(\theta_{0}\right)$ of each corner. The lower values on the $\mathrm{X}$-axis in Fig. 3 (percentage of the number of representative items) indicate that NRI was converted as a percentage. When the units of the $\mathrm{X}$ - and $\mathrm{Y}$-axes are heterogeneous, the interior angle of each point cannot be used as criteria that indicate changes (Orit et al. 2002). Therefore, all the units were converted into percentages, identical to $\mathrm{CR}$, by dividing the selected NRI by the number of collected items.

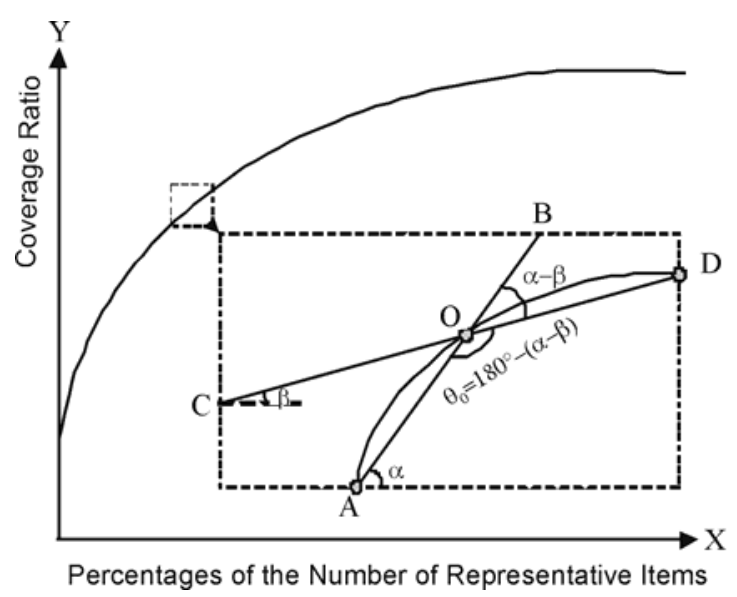

Fig. 3. Measurement of the interior angle of each point

To obtain the interior angle, a tangent formula (equation (5)) calculates an intersect angle created by the two lines among the various trigonometric functions $(\alpha-\beta$ in Fig. 3) (Jeffrey 2003). Equation (6) is derived from equation (5) to obtain an intersect angle. As shown in equation (7), one can select the minimum value among the calculated intersect angles.

$$
\begin{aligned}
& \tan (\alpha-\beta)=\left|\frac{\tan \alpha-\tan \beta}{1+\tan \alpha \tan \beta}\right|, \\
& \alpha-\beta=\tan ^{-1}\left|\frac{\tan \alpha-\tan \beta}{1+\tan \alpha \tan \beta}\right|,
\end{aligned}
$$

where, $\tan \alpha$ and $\tan \beta$ are the slopes of lines $A B$ and $C D$, respectively, and $\alpha-\beta$ is an intersect angle of lines $A B$ and $C D$.

$$
\text { Minimun }\left\{\theta_{0}=180-(\alpha-\beta)\right\} \text {, }
$$

where $\theta_{0}$ is an angle of AOD.

Fig. 4 shows the procedure of the SMRI which consists of 1) collecting pre-filtered items, 2) calculating the weights, 3) rearranging the items in the ascending order of weights, and 4) calculating CR, NRI, PNRI, tan $\alpha$ and $\beta$. Since the SMRI has no ability to filter the unreliable data, selecting the pre-filtered items ((1)-(10) in Fig. 4) through human knowledge is needed. The procedure 


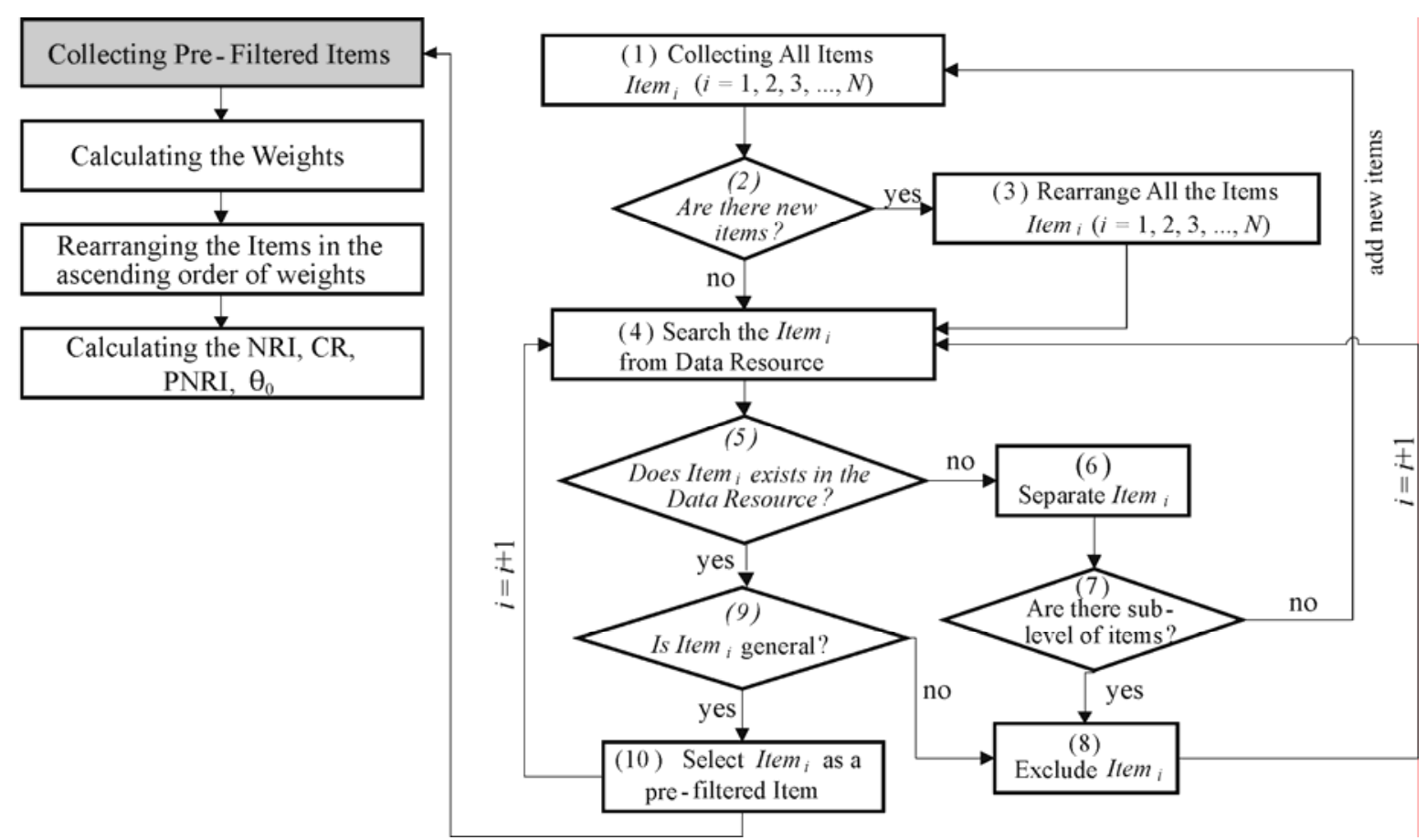

Fig. 4. Procedure of the SMRI

inspects the availability ((4)-(7) in Fig. 4) and generality ((9)) of collected items. The available items mean that the items exist in the data resources. In other words, unit prices can be obtained continuously from the data resources. The general items indicate that the items are normally used for the project type. First, compilers should check out whether unit price of the item (item ${ }_{i}$ in Fig. 4) can be obtained from the data resource after collecting all items priced BOQs. In many cases, the items included in the BOQs are organized into sub-level of items. For example, wall forming consists of carpenter, coating plywood, nail, and so forth. It is necessary to separate the item into sub-level of items in order to increase the CR. The sub-level of items are included in the population whereas the upper-level of item (e.g., wall forming) is excluded for removing redundancy. Finally, the pre-filtered items are sequentially collected while the updated population repeatedly takes the procedure.

Table 4 shows the result that the priced BOQ of one public multi-family housing project constructed in 2003 was applied to the developed SMRI. After arranging the collected items from those with the smallest CR to those with the largest, the PNRI was calculated. For example, the PNRI (\%) of the $11^{\text {th }}$ item is the ratio of the number of applied items to the number of all the collected items $(42.31 \%=(11 / 26) \times 100)$. Moreover, CR $(96.44 \%)$ is the value obtained by adding the CR (up to the $10^{\text {th }}$ item $(94.24 \%))$ to the weights of the $11^{\text {th }}$ item $(2.2 \%)$.

Tan $\alpha(0.57)$ of the steel bar (HD 16) is the value of the difference between the CRs $(2.2=96.44-94.24)$ of the steel bar (HD 16) and the wall panel (No. 17) divided by the difference between the PNRIs $(3.85=42.31-$ $38.46)$ of the two items $(0.57=2.2 / 3.85)$. Tan $\beta(0.26)$ of the steel bar (HD 16) is the value of the difference between the CRs ( $1=97.44-96.44)$ of the coating ply- wood (No. 15) and the steel bar (HD 16) divided by the difference between the PNRIs (3.84 = 46.15 - 42.31) of the two items $(0.26=1 / 3.84) . \theta_{0} 164.84^{\circ}$ of the steel bar (HD 16) is the value obtained when $15.16^{\circ}$ is subtracted from $180^{\circ}$, which can be calculated using equation (8).

$$
\alpha-\beta=\tan ^{-1}\left|\frac{0.57-0.26}{1+0.57 \cdot 0.26}\right|=15.16 .
$$

As shown in column 8 of Table 4, the interior angle of the steel bar (HD 16) is at a minimum, which means that the 11 items, including the steel bar (HD 16), are the most effective representative items among the 26 items. If there is an identical interior angle, only the interior angle that has a higher CR can be chosen. As shown in Fig. 5, the right part of the curved line (15 items) is almost flat.

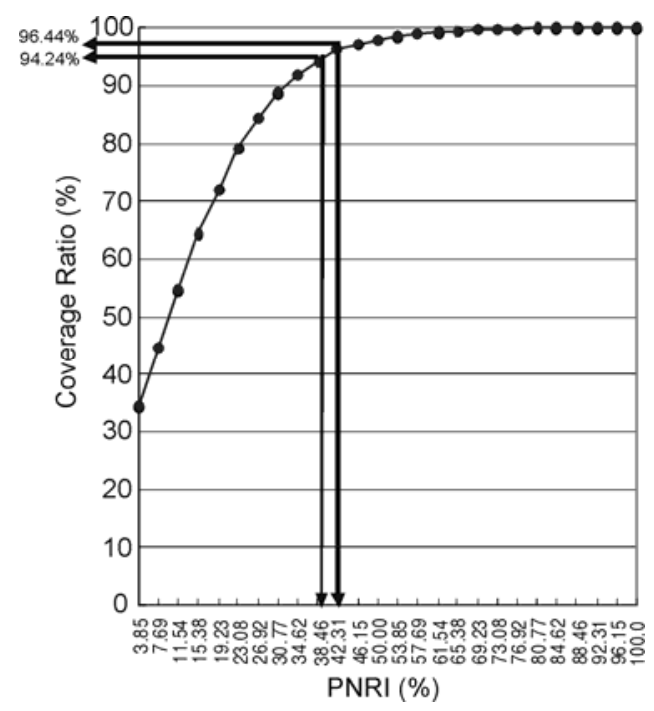

Fig. 5. Curved line for the example 
Table 4. Sample Calculation of the Interior Angles

\begin{tabular}{|c|c|c|c|c|c|c|c|c|c|}
\hline (1) & $(2)$ & (3) & (4) & (5) & (6) & (7) & (8) & (9) & $(10)$ \\
\hline No. & Item & Cost & Weight & NRI* & CR (\%) & PNRI (\%) & $\theta_{0}$ & $\operatorname{Tan} \alpha$ & $\operatorname{Tan} \beta$ \\
\hline 1 & Spacer (slab) & 171,945 & 0.00 & 26 & 100.00 & 100.00 & - & 0.00 & N/A \\
\hline 2 & Spacer (column) & 423,953 & 0.00 & 25 & 99.99 & 96.15 & 179.80 & 0.01 & 0.00 \\
\hline : & & $:$ & & : & & $:$ & & & $:$ \\
\hline 16 & Hook cramp & $11,601,623$ & 0.01 & 13 & 98.06 & 50.00 & 178.90 & 0.16 & 0.14 \\
\hline 15 & $\begin{array}{l}\text { Coating plywood } \\
\left(12 \mathrm{~mm} 4^{\prime * 8}\right)\end{array}$ & $18,677,233$ & 0.01 & 12 & 97.44 & 46.15 & 174.59 & 0.26 & 0.16 \\
\hline 16 & Steel bar (HD16) & $41,000,000$ & 0.02 & 11 & 96.44 & 42.31 & 164.84 & 0.57 & 0.26 \\
\hline 17 & Wall panel $(600 * 1200)$ & $44,226,762$ & 0.02 & 10 & 94.24 & 38.46 & 178.09 & 0.62 & 0.57 \\
\hline 18 & Steel bar (HD25) & $56,500,000$ & 0.03 & 9 & 91.86 & 34.62 & 173.43 & 0.79 & 0.62 \\
\hline 19 & Concrete (25-240-15) & $81,408,000$ & 0.04 & 8 & 88.83 & 30.77 & 169.61 & 1.14 & 0.79 \\
\hline 20 & Steel bar (HD22) & $98,500,000$ & 0.05 & 7 & 84.46 & 26.92 & 174.68 & 1.37 & 1.14 \\
\hline 21 & Steel bar (HD10) & $136,680,000$ & 0.07 & 6 & 79.18 & 23.08 & 171.63 & 1.91 & 1.37 \\
\hline 22 & Steel bar (HD13) & $138,370,000$ & 0.07 & 5 & 71.85 & 19.23 & 179.71 & 1.93 & 1.91 \\
\hline 23 & Concrete (25-210-12) & $181,496,000$ & 0.10 & 4 & 64.42 & 15.38 & 174.17 & 2.53 & 1.93 \\
\hline 24 & Steel bender & $188,229,924$ & 0.10 & 3 & 54.68 & 11.54 & 179.30 & 2.63 & 2.53 \\
\hline 25 & Concrete (25-240-12) & $190,332,000$ & 0.10 & 2 & 44.58 & 7.69 & 179.79 & 2.66 & 2.63 \\
\hline \multirow[t]{2}{*}{26} & Carpenter & $640,623,088$ & 0.34 & 1 & 34.37 & 3.85 & - & N/A & 2.66 \\
\hline & Total amount & $1,863,791,039$ & & & & & & & \\
\hline
\end{tabular}

\section{Case study}

To verify the usability of the proposed SMRI, a case study was conducted, for which collected 44 items were collected from the RC works of 10 multi-family housing projects ordered between 2003 and 2006. These projects are different from the 30 projects that were used in chapter 3 . Table 5 shows the summary of the projects. The gross floor area (GFA) of the projects is 79,190 $\mathrm{m}^{2}$ on average. The numbers of floors (NFs) range from 5 to 15. The structural type is almost similar to the foundation. The proposed SMRI selects representative items out of these items. 44 items as pre-filtered representative items out of 53 items are selected by Fig. 4.

Table 5. Summary of 10 Multi-Family Housing Projects

\begin{tabular}{c|c|c|c|c}
\hline No. & $\begin{array}{c}\text { GFA* } \\
\left(\mathrm{m}^{2}\right)\end{array}$ & $\begin{array}{c}\text { NF** } \\
\text { (above) }\end{array}$ & $\begin{array}{c}\text { Structural } \\
\text { Type }\end{array}$ & Foundation \\
\hline 1 & 37,426 & $12 \sim 5$ & RC & Pile \\
\hline 2 & 65,318 & $11 \sim 14$ & RC & Mat+Pile \\
\hline 3 & 112,934 & $11 \sim 15$ & RC & Pile \\
\hline 4 & 92,427 & $11 \sim 15$ & RC & Mat+Pile \\
\hline 5 & 84,759 & $12 \sim 15$ & RC & Pile \\
\hline 6 & 60,706 & $12 \sim 15$ & RC & Pile \\
\hline 7 & 80,749 & $10 \sim 15$ & RC & Pile \\
\hline 8 & 52,879 & $5 \sim 14$ & RC & Pile \\
\hline 9 & 110,663 & 15 & RC & Pile \\
\hline 10 & 94,038 & 15 & RC & Pile \\
\hline
\end{tabular}

Note: *GFA = gross floor area; $* * \mathrm{NF}=$ number of floors.

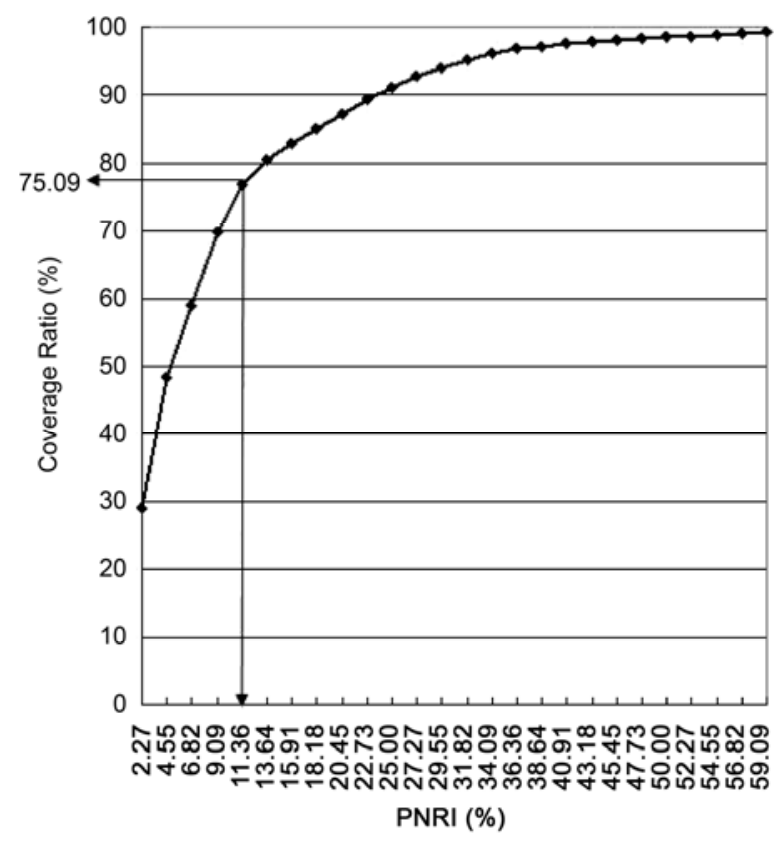

Fig. 6. Curved line of the RC works of the 10 projects

Fig. 6 represents the curved line which shows relationship between CR and PNRI of the items included the RC works of the 10 multi-family housing projects.

Table 6 shows the interior angle of each item. In the 5th item (column (6) of Table 6), the interior angle is at a minimum. Five representative items, from the 5th steel bar (HD25) to the 44th carpenter item, were selected out of the total of 44 items. As shown in Figure 6, the CR and 
PNRI of the steel bar (HD13) are $75.09 \%$ and $11.36 \%$, respectively. Table 6 also shows efficiency $\left(e^{*}\right)$ of each point for observing the changing ratios $(\Delta e)$. For example, the $e^{*}$ (1.66) of concrete (25-210-12) can be calculated by dividing difference of CRs into that of PNRIs (1.66 = $(78.87-75.09) /(13.64-11.36))$. The $\Delta e(99.94=$ $(3.32-1.66) * 100 / 1.66)$ of concrete $(25-210-12)$ means that Concrete (25-21-12) have the lowest efficiency.

As shown in Fig. 7, the interior angles decreased from the first to the fifth items while the remainder of the interior angles increased on average.

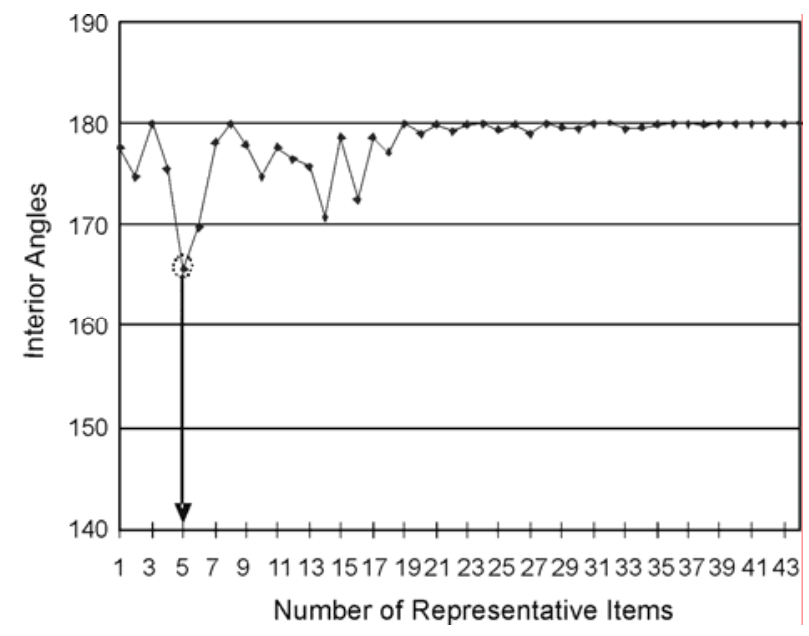

Fig. 7. Interior angles

\section{Conclusions}

Subcontractors have played an important role in the construction industry. Unfortunately, cost indexes focus on representative items with higher weights from a macroscale viewpoint. To address this limitation, a selection model for representative items (SMRI) for subcontractors was proposed in this paper.

The priced BOQs of 30 multi-family housing projects were used to derive the characteristics of the subcontractors' costs. The curve estimation of SPSS12.0 showed that the cubic model has the highest $\mathrm{R}^{2}$ and can cover more than $80 \%$ of the coverage ratio using $28.17 \%$ of the representative items. This means that the relationship between the coverage ratio and the percentage of NRI follows Pareto's principle.

Based on the study results, an SMRI for subcontractors was developed in this study by applying a mathematical approach. The SMRI can select representative items that considerably influence the subcontractors' cost index, using the tangent function out of the various trigonometric functions. The SMRI generally consists of (i) the stage in which the collective items' weights are calculated; (ii) the stage in which the CR and PNRI (\%) are calculated; and (iii) the stage in which representative items are selected based on the calculated interior angle.

In the case study that was conducted, the feasibility of the developed model was verified by using 10 multifamily housing projects ordered between 2003 and 2006. It was found that $11.36 \%$ of the representative items can cover $75.09 \%$ of the CR, and that the SMRI can select more effective representative items compared to the prevailing method.

Table 6. Interior Angle of Each Item

\begin{tabular}{|c|c|c|c|c|c|c|c|c|c|}
\hline $\begin{array}{l}\text { (1) } \\
\text { No. }\end{array}$ & $\begin{array}{l}\text { (2) } \\
\text { Item }\end{array}$ & $\begin{array}{l}\text { (3) } \\
\text { Cost }\end{array}$ & $\begin{array}{l}\text { (4) } \\
\text { Weight }\end{array}$ & $\begin{array}{l}\text { (5) } \\
\text { NRI }\end{array}$ & $\begin{array}{l}\text { (6) } \\
\text { CR (\%) }\end{array}$ & $\begin{array}{l}\text { (7) } \\
\text { PNRI (\%) }\end{array}$ & $\begin{array}{l}(8) \\
\theta_{0}\end{array}$ & $\begin{array}{l}\text { (9) } \\
e^{*=\Delta C R} \\
/ \Delta P N R I\end{array}$ & $\begin{array}{l}(10) \\
\Delta e\end{array}$ \\
\hline & Spacer (slab) & $3,280,560$ & 0.00 & 44 & 100.00 & 100.00 & - & 0.00 & 28.30 \\
\hline & Skilled labor & $4,208,963$ & 0.00 & 43 & 100.00 & 97.73 & 179.98 & 0.00 & 30.39 \\
\hline & & : & & $:$ & & : & & & : \\
\hline 31 & Steel plate (T0.2) & $1,528,478,763$ & 0.01 & 14 & 94.90 & 31.82 & 170.72 & 0.56 & 18.08 \\
\hline 32 & Concrete (25-240-12) & $1,804,824,568$ & 0.02 & 13 & 93.62 & 29.55 & 175.77 & 0.66 & 13.99 \\
\hline 33 & Wall panel $(600 * 1200)$ & $2,057,379,292$ & 0.02 & 12 & 92.12 & 27.27 & 176.46 & 0.76 & 8.86 \\
\hline 34 & Concrete (25-180-12) & $2,239,665,405$ & 0.02 & 11 & 90.40 & 25.00 & 177.64 & 0.82 & 20.13 \\
\hline 35 & Steel bar (HD19) & $2,690,579,605$ & 0.02 & 10 & 88.53 & 22.73 & 174.78 & 0.99 & 7.44 \\
\hline 36 & Steel bar (HD22) & $2,890,781,729$ & 0.02 & 9 & 86.29 & 20.45 & 177.94 & 1.06 & 0.26 \\
\hline 37 & Steel bar (HD16) & $2,898,412,926$ & 0.02 & 8 & 83.87 & 18.18 & 179.92 & 1.06 & 6.99 \\
\hline 38 & Steel bar (HD25) & $3,100,927,978$ & 0.03 & 7 & 81.45 & 15.91 & 178.07 & 1.14 & 45.87 \\
\hline 39 & Concrete (25-210-12) & $4,523,288,002$ & 0.04 & 6 & 78.87 & 13.64 & 169.76 & 1.66 & 99.94 \\
\hline 40 & Steel bar (HD13) & $9,043,698,358$ & 0.08 & 5 & 75.09 & 11.36 & 165.71 & 3.32 & 38.01 \\
\hline 41 & Steel bender & $12,481,001,579$ & 0.10 & 4 & 67.55 & 9.09 & 175.55 & 4.58 & 0.84 \\
\hline 42 & Steel bar (HD10) & $12,585,783,003$ & 0.11 & 3 & 57.13 & 6.82 & 179.90 & 4.62 & 77.15 \\
\hline 43 & Concrete (25-240-15) & $22,295,378,471$ & 0.19 & 2 & 46.63 & 4.55 & 174.75 & 8.19 & 50.65 \\
\hline \multirow[t]{2}{*}{44} & Carpenter & $33,587,015,252$ & 0.28 & 1 & 28.03 & 2.27 & 177.67 & 12.33 & - \\
\hline & Total amount & $119,841,760,095$ & & & & & & & \\
\hline
\end{tabular}

Note: *e = efficiency 
If the data resources of other fields, such as the World Bank's consumer price index, which requires information regarding 80,000 representative items every month, follow Pareto's principle, the proposed SMRI can be applied to the field. It is necessary, however, to develop or select an index formula that is tailored to the characteristics of each data resource because an index number is calculated by applying the data resources to an index formula.

\section{Acknowledgment}

This research was supported by a grant (05CIT-D05-01) from Construction Technology Innovation Program funded by Ministry of Land, Transportation and Maritime Affairs of Korea government.

\section{References}

Balk, B. M. 1995. Axiomatic Price Index Theory: A survey, International Statistical Review 63(1): 69-93. doi:10.2307/1403778

Barrie, D. S., and Paulson, B. C. 1992. Professional Construction Management. $3^{\text {rd }}$ ed. McGraw-Hill Book. 198-205.

Bates, W. and Dawood, N. 1997. Development of a computerised cost indices forecasting model for construction activities in the heavy civil engineering industry, in Proc. of the Mouchel Centenary Conference on Innovation in Civil and Structural Engineering, 19-21 August 1997, Cambridge, England, 189-198.

California Department of Transportation (Caltrans). 2006. Cost Index Summary [online], [accessed 8 June 2006]. Available from Internet: <http://www.dot.ca._gov/hq/esc/ oe/contract_progress/cost-index-summary_.pdf $>$.

Dawood, N. 1999. Development of a forecasting methodology for cost indices in the Greek construction industry, in Profitable Partnering in Construction Procurement, Routledge, UK, 627-636.

Fleming, M. C., and Tysoe, B. A. 1991. Spon's Construction Cost and Price Indices Handbook. Taylor \& Francis Group: Spon Press.

Hassanein, A. and Khalil, B. 2006. Building Egypt 1 - a general indicator cost index for the Egyptian construction industry, Engineering, Construction and Architectural Management 13(5): 463-480. doi:10.1108/09699980610690747

International Monetary Fund (IMF). 2004. Basic Index Number Theory [online], [accessed 22 November 2005]. Available from Internet: <http://www.imf.org/ external/np/sta_/ tegeipi/ch12.pdf $>$.
Jeffrey, A. 2003. Handbook of Mathematical Formulas and Integrals. $3^{\text {rd }}$ ed. Elsevier Academic Press, Boston.

Kim, W. Y., and Kim, Y. J. 2005. Development of Construction Cost Index III. Seoul: Construction and Economy Research Institute of Korea.

Korea Institute of Construction Technology (KICT). 2004. Material for education of estimate using historical cost [online], [accessed 23 November 2004]. Available from Internet: <http://www.kict.re.kr/ division/quality/cost ngineering/ reference_room.asp> .

Orit, Z.; Hagit, S., and Uri, L. 2002. Being sloppy about slope: The effect of changing the scale, Educational Studies in Mathematics 49(1): 119-140. doi:10.1023/A:1016093305002

Stock, J. H., and Watson, M. W. 2007. Introduction to Econometrics. $2^{\text {nd }}$ ed. Person International Edition, Boston.

The Bank of Korea 2005. Understandable Explanation for Economic Indicators [online], [accessed 15 January 2005]. Available from Internet: <http://www.bok.or.kr/ index.jsp>.

The World Bank 2006. ICP Chapter 12: Aggregation Methods [online], [accessed 7 Jan. 2006]. Available from Internet: $<$ http//siteresources. worldbank_org/ICPINT/Resources/ ch12.doc $>$.

Tim, G. 2005. First quarterly cost report, in Engineering News Record (ENR). McGraw Hill, 35.

Ulubeyli, S. and Kazaz, A. 2009. A multiple criteria decision making approach to the selection of concrete pumps, Journal of Civil Engineering and Management 15(4): 369-376. doi:10.3846/1392-3730.2009.15.369-376

US Army Corps of Engineers 2000. Engineering and design civil works construction cost index system, in Engineer Manual. Washington: US Army Corps of Engineers, 10 12.

Wang, C. H. and Mel, Y. H. 1998 Model for forecasting construction cost indices in Taiwan, Construction Management and Economics 16(2): 147-157. doi:10.1080/014461998372457

Washington State Department of Transportation (WSDOT) 2006. Bid Tabulation File for December 2006 [online], [accessed 3 March 2007]. Available from Internet: $<$ http://www.wsdot.wa.gov/ biz/contaa/_BIDTAB/default.htm>.

Wilmot, C. G., and Cheng, G. 2003. Estimating future highway construction cost, Journal Construction Engineering and Management - ASCE 129(3): 272-279. doi:10.1061/(ASCE)0733-9364(2003)129:3(272)

\section{TIPINIŲ PRODUKTŲ ATRANKOS MODELIS SUBRANGOVŲ SĄNAUDŲ RODIKLIUI NUSTATYTI DAUGIABUČIU NAMŲ PROJEKTUOSE}

\section{S.-Ch. Park, T. H. Hong, K.-J. Koo, Ch.-T. Hyun}

\section{$\mathrm{S}$ a n tra u k}

Kainos rodiklis yra labai svarbus analizuojant igyvendintus projektus ir yra tiriamas naudojamų tipiniu produktu pramonèje. Tai plačiai naudojamas pramonès veiklos rodiklis, tačiau nedaugeliui tipinių produktų būdingas platus kainų diapazonas. Statybos pramonė apima įvairias paslaugų rūšis, kurių daugelį teikia subrangovai. Deja, esami kainos rodiklio subrangovų išlaidų svyravimai sunkiai kontroliuojami, nes tipiniai produktai, tokie kaip statybos būdas ar gebẻjimai, atrenkami makroskalès požiūriu. Todèl šis tyrimas buvo atliktas siekiant sukurti atrankos modelỉ, pagal kurị būtų galima pasirinkti naudingiausią tipini produktą ir įvertinti subrangovų išlaidas. Subrangovų sąnaudų charakteristikoms nustatyti taikyti kreivès funkcijos skaičiavimai SPSS ${ }^{\circledR} 12.0$ Windows, naudoti 30 daugiabučių namų projektu įkainojimo dokumentai. Tyrimų rezultatai rodo, kad santykis tarp apimčių koeficiento ir tipinių produktų procento pagristas Pareto principu. 
Juo remiantis buvo sukurtas tipinių produktų atrankos modelis, taikant tangento funkciją. Atvejo tyrimas, atliktas siekiant patikrinti modelio naudojima, atskleide, kad numatomas atrankos modelis gali racionaliai parinkti kiekvieno subrangovo darbus pagal naudingiausius tipinius elementus, kurie įtraukti ị daugiabučių namų projektus.

Reikšminiai žodžiai: gyvenamujų namų statybos projektai, tipiniai produktai, atrankos modelis, kainos rodiklis, subrangovų išlaidos, tangento funkcija, sąnaudų rodiklis.

Sung-Chul PARK is a doctor in the Educational Facilities Research and Management Center(EDUMAC) of Korean Educational Development Institute(KEDI). He is a member of KSCE, AIK, KICEM. His research interests include Construction Optimization, Construction Data Mining, and Ubiquitous-Eco school.

TaeHoon HONG is an assistant professor at the Department of Architectural Engineering of Yonsei University, Seoul, Korea. He is a corresponding member of editorial board in the Journal of Management in Engineering, ASCE and is also a member of academic or practical institute such as AIK, KSCE, ASCE, KICEM and KCVE. His main research areas include life cycle cost analysis, life cycle assessment, infrastructure asset management, facility management, and construction project cost control.

Kyo-Jin KOO is an associate professor at the Department of Architectural Engineering of the University of Seoul, Korea. He is the head of Research \& Development Committee of KICEM. His research interests include integration of time and cost information, construction data warehouse, and innovative contracting methods.

Chang-Taek HYUN is a professor at the department of Architectural Engineering of the University of Seoul, and also working as a president of KCVE(Korea Construction VE Research Institute). And he is a member of academic or practical institute such as AIK, KICEM, ASCE, CMAA, and SAVE I. The major focus of his research is on Construction Engineering \& Management including Value Engineering/Life Cycle Cost, Construction Delivery methods, and Building Construction. 